\title{
Risk factors in the leading sustainable development for the Nizhny Novgorod Region
}

\author{
Tatiana Zykova \\ Institute of Economics and Entrepreneurship \\ National Research University \\ Gagarin str. 23, 603950, Nizhny Novgorod \\ Russian Federation \\ e-mail: tanya.5036@mail.ru \\ Elena Kochkurova \\ Institute of Economics and Entrepreneurship \\ National Research University \\ Gagarin str. 23, 603950 Nizhny Novgorod, \\ Privolzhsky Research Medical University \\ pl. Minin and Pozharsky, 10/1, 603950, Nizhny Novgorod \\ Russian Federation \\ e-mail: elenakochkurova@mail.ru
}

\begin{abstract}
This paper reviews and systematizes the risk factors having an influence on the sustainable development of the tourism industry - one of the leading and especially promising development sectors of the Nizhny Novgorod region. The paper examines weaknesses, threats and risks of the tourist industry in the region. Further, it analyzes the state of the tourist sphere of the Nizhny Novgorod region over the past few years. In addition, the paper presents an analysis of the risk factors that are typical for tourism in the area under study. Using the method of analyzing hierarchies and involving an expert group, the identified factors were ranked to identify those having the greatest impact on the development of tourism in the Nizhny Novgorod region.

We establish the relationship and analyze the degree of influence of the identified risk factors on the development of tourism in the region is determined based on statistical indicators analysis. Moreover, we propose measures that would enable to manage risks through the application of competent public policies and strategies for the development of the tourism industry.
\end{abstract}

\section{Introduction}

The interpretation of the "risk" concept is diverse like the application of this definition in many different spheres of our life. According to the economic dictionary, a risk is a possibility of an unfavorable situation or an unsuccessful outcome of industrial and business operations or any other activity. From the mathematical standpoint, a risk is treated as the ratio of favorable and unfavorable outcomes of an event in relation to the total number of outcomes (Subačienè et al. 2018). In the sphere of tourism, a risk is the basic and integral part of business, which is adopted, systematized and subjected to management in order to prevent the emergence of a crisis situation or to minimize losses (Bikas and Saponaite 2018).

In the modern context, tourist industry is associated with various types of risks, representing an entire system. In the opinion of several authors, many risk studies are focused on specific areas, the risk in the tourist industry is fragmented, and therefore there is a need to understand the different concepts of tourist risks and their manifestation in different scales of activity (Ioannides et al. 2001; Strielkowski et al. 2012; Williams and Baláž 2014; Piekarz et al, 2015; Karl 2016). In fact, the tourist industry operates in conditions of total uncertainty and the risk management in this area requires the following tasks: i) identification of the risk causes and circumstances; ii) development of an effective mechanism for managing the tourism in a risk and uncertainty environment; iii) adoption of managerial decisions aimed at overcoming the negative consequences caused by risk (Degaev 2014; Yang 2015; Oláh et al. 2017; or Abrhám and Wang 2017).

This paper is focused on the risk factors of sustainable economic development of Nizhny Novgorod region as a leading region in this part of Russia. We perceive the notion of region's leadership as the one embedded with potentials, economic gains, and opportunities for further growth and development (see e.g. Strielkowski and Chigisheva 2018). The paper employs the Saati's method of analyzing hierarchies and involving an expert group. 


\section{Internal and external risk factors}

In order to identify the risk causes and circumstances, it is necessary to analyze risk factors in the region under study. A factor is the reason, the driving force of a process, determining its nature or individual features (Han and Song 2017). We split the factors affecting the problem of tourism development, into internal and external ones by their sphere of influence. The external factors include as follows:

1. Physical and natural factors, including environmental conditions, climate, terrain, proximity to the sea, the presence of specific conditions for the stay of people with certain types of diseases (León et al., 2014)

2. Historical and cultural factors that characterize the history of the region, the presence of architectural monuments, places of pilgrimage and historical monuments in the region.

3. Demographic and mental factors that characterize the age and sex composition of the population, demographic indicators, the level of education of the population, the average standard of living of the population, the mentality, the nature and customs of the country or region.

4. Economic factors. The development of the tourist industry has a great impact on the economy of the region, therefore, such indicators as follows are subject to the analysis: the share of tourism in the GDP, the size of the tourist flow, the quality of the material and technical base, the interindustry balance of tourism with other production and non-productive areas of the region, the international level of cooperation and collaboration, the presence of integration associations (Poudel et al. 2014; Strielkowski 2017; 2018; Chen et al. 2018; Hen et al. 2018).

5. Social and political factors, which primarily mean the safety of tourists in the region. They characterize the degree of interethnic tension, crises, political instability, etc. (Kirillova 2017).

The internal factors should be divided into the following groups:

1. Infrastructural (technical) factors. They imply analysis of transport links, roads, the degree of accessibility of tourist facilities, as well as the level of hotel services, the number of hotels, the level of restaurant business, gambling establishments and other companies that provide a full rest for tourists.

2. Environmental factors that characterize the level of environmental pollution in the region associated with the development of industrial production, various levels of natural and man-made disasters that affect the occurrence of tourist risks.

3. Personnel component, including the factors of training personnel in the tourism industry and influencing the emergence of risks of reducing the level of service due to low skills of staff, ignorance of foreign languages, etc.

4. Marketing (market) factor: The level of advertising, information openness, the region brand and business reputation, the image of recreation in a particular region

5. Innovative factors: The high-tech tourism (space tourism), new non-traditional kinds of tourism, connected with new kinds of sports or application of new kinds of equipment (for example, excursion service on segways) are becoming increasingly popular (Andergassen et al. 2017).

\section{Regional assessment of risk factors}

The area under investigation - the Nizhny Novgorod region is a dynamically developing tourist and recreational zone of Russia (Kochkurova and Zykova 2018). Over the past 10 years, the flow of tourists visiting the region has more than doubled and the dynamics persists. According to the forecast, by 2020 the region will be visited by more than three million people annually. According to statistics, the tourist flow in recent years, on average, increases by $10 \%$ every year, in 2015 there was a decrease in flow due to the reduction of tourists from abroad, but in 2016 there was a sharp jump in the tourist flow, it increased by $34 \%$ compared to the previous year (Table 1).

Table 1. Dynamics of tourism development indicators in the Nizhny Novgorod region in 2013-2016

\begin{tabular}{|c|c|c|c|c|}
\hline & 2013 & 2014 & 2015 & 2016 \\
\hline $\begin{array}{c}\text { Tourist flow to the Nizhny Novgorod region, } \\
\text { '000 people }\end{array}$ & 1027,605 & 1143,45 & 1089 & 1459,26 \\
\hline Number of hotels & 143 & 171 & 198 & 257 \\
\hline One-time bedspace & 9880 & 15797 & 20117 & 32560 \\
\hline
\end{tabular}

Source: Oppenov (2018) 
Strategic management of the development of the tourist industry requires identifying the main risk factors for the development of the tourist industry and their timely elimination or leveling the situation through the adoption of preventive measures to ensure sustainable development of tourism in the region (Nordin 2003).

In the groups of identified main factors - sources, causes of risks, we characterize the main risks inherent in the Nizhny Novgorod region:

1. Physical and natural factors. The unique nature of the Nizhny Novgorod region is rather its advantage than the risk, but the division of region by the river Volga into two separate parts makes individual tourist attractions of the region hard-to-get.

2. The historical and cultural heritage of the region is very rich. On the territory of the region there is the Boldino manor, where a famous Russian poet Alexander Pushkin wrote his best works, and the ancient buildings of feudal times survive to these days. However, it should be noted that the monuments of antiquity are in a sad state and require reconstruction.

3. Demographic factors. The low living standards of the population in the region under study provoke a high level of outbound migration. Many young people tend to leave their native places in search of a better life. The level of assimilation (sedentary) of the population is very low.

4. Economic factors. The most significant is the impact of the economic crisis on a countrywide scale, which has reduced the tourist flow to the Nizhny Novgorod region. In addition, the region is characterized by low labor productivity, which justifies a low level of wages even in industrial sectors. The most important problem of the region is the limitation of the energy system. As the main problem existing in the region, experts called the underdevelopment of the main and distribution networks, as well as the high degree of deterioration of generating capacities.

5. Social and political factors. Basically, the author characterizes the political stability of the region. As a risk, it is necessary to highlight the lack of state support for the development of the tourist industry in the Nizhny Novgorod region.

6. Infrastructural factors. One of the main problems of the road economy of the Nizhny Novgorod region is the lack of crossings of a permanent type through such large rivers as Volga, Oka, Sura. Thus, the connection of the northern and southern parts of the Nizhny Novgorod region, disunited by the Volga river, is currently being carried out along two permanent crossings: the bridge across the river Volga on the Nizhny Novgorod - Shakhunya - Kirov highway and a section of the Linda - Gorodets - Zavolzhye road, passing along the crest of the dam of the Gorky reservoir (Krivov 2012). This creates a traffic congestion in the crossing points to $70 \%$, which significantly complicates the movement over the region. It should also be noted that access to the northern part of the region is significantly hampered, no convenient by-pass for transit traffic across the region, and also a limited passability of the Volga river channel.

7. Environmental factors. The Nizhny Novgorod region is surrounded on all sides by industrial centers, and the main share in the gross regional product is the income from industrial production. As a result, air pollution in the Nizhny Novgorod region is very high, in some areas contamination reaches 4 MPC (maximum permissible concentration) (Krivov 2012).

8. Personnel component. Low level of foreign tourism is justified by the lack of sufficient information in English and other languages. The qualification of the personnel involved in the tourist industry is very low, which is explained by the low living standards of the population, the low level of hotel services, including the staff. The lack of financial resources, as well as the lack of state support, makes any changes in this area impossible.

9. Marketing factors. The Nizhny Novgorod region is characterized by total lack of advertising, low level of service of the hotel and restaurant businesses, information vacuum. Despite the unique geographical location, as well as historical and cultural heritage, this region is hardly attractive for tourists for the reason of the lack of information and advertising.

10. Innovative factors. Innovative development of tourism is rather a strong side of the region, than the reason for the emergence of risks of sustainable development. In the Nizhny Novgorod region, a tourist cluster was formed, within which active tourism development is taking place. In places of reconstruction of historical sites, restaurants, hotels, etc. are developing. In addition, the media note the development of extreme tourism in the region, e.g. flights on MiG fighters for VIP guests. The cost of such a pleasure starts from 600 thousand rubles. But not less money will be spent by rich tourists for two weeks of preparing for the flight. As they will live in expensive hotels, corresponding to their level, have meal in restaurants, and go on excursions (Borisov 2015).

In order to ensure the sustainable development of the tourism industry, it is necessary to identify the most significant risks, which will improve the efficiency of the consumption of limited resources in the region. Ranking of risks and identification of the most dangerous and affecting the economy of the region was carried out using the Saati's Analytic Hierarchy Process. Points for each group of risk factors were assigned by the degree of influence on the economy of the Nizhny Novgorod region from the point of view of experts. A group 
of experts was assembled from 5 people (members of municipalities of the largest cities of the region). Method of collecting information is written questionnaires and interviews. An example of the ranking factors of one of the experts is shown in Table 2 .

Table 2. Identification of significant risk factors for tourism development in the Nizhny Novgorod region

\begin{tabular}{|l|c|c|c|c|c|c|c|c|c|c|c|}
\hline & 1 & 2 & 3 & 4 & 5 & 6 & 7 & 8 & 9 & 10 & $\mathrm{Bec}$ \\
\hline 1. Physical risk factors & 1 & $1 / 3$ & $1 / 4$ & $1 / 4$ & 2 & $1 / 5$ & $1 / 7$ & 1 & $1 / 3$ & 3 & 8,510 \\
\hline $\begin{array}{l}\text { 2. Historical and cultural risk } \\
\text { factors }\end{array}$ & 3 & 1 & 3 & $1 / 5$ & 3 & 3 & $1 / 5$ & 5 & 3 & 1 & 22,400 \\
\hline 3. Demographic risk factors & 4 & $1 / 3$ & 1 & 1 & 3 & 1 & $1 / 3$ & 1 & $1 / 5$ & 1 & 12,867 \\
\hline 4. Economic risk factors & 4 & 5 & 1 & 1 & 3 & 3 & 1 & 3 & 1 & 1 & 23,000 \\
\hline $\begin{array}{l}\text { 5. Social and political risk } \\
\text { factors }\end{array}$ & $1 / 2$ & $1 / 3$ & $1 / 3$ & $1 / 3$ & 1 & $1 / 5$ & $1 / 5$ & 1 & $1 / 3$ & 1 & 5,233 \\
\hline 6. Infrastructure risk factors & 5 & $1 / 3$ & 1 & $1 / 3$ & 5 & 1 & 1 & 5 & 1 & 1 & 20,667 \\
\hline 7. Environmental risk factors & 7 & 5 & 3 & 1 & 5 & 1 & 1 & 5 & 1 & 3 & 32,000 \\
\hline 9. Personnel risk factors & 1 & $1 / 5$ & 1 & $1 / 3$ & 1 & $1 / 5$ & $1 / 5$ & 1 & $1 / 3$ & 1 & 6,267 \\
\hline 10. Marketing risk factors & 3 & $1 / 3$ & 5 & 1 & 3 & 1 & 1 & 3 & 1 & 1 & 19,333 \\
\hline 11. Innovation risk factors & $1 / 3$ & 1 & 1 & 1 & 1 & 1 & $1 / 3$ & 1 & 1 & 1 & 8,667 \\
\hline
\end{tabular}

Source: Own results

Based on the results of the analysis of one expert, one can see that the economy of the region in the most influenced by environmental, infrastructural, marketing and demographic factors. In the opinion of all experts participating in the survey it is necessary to adjust the results of the analysis. The adjusted results are shown in Table 3.

Table 3 Analysis of expert opinions and adjustment of results

\begin{tabular}{|l|c|c|c|c|c|c|c|c|c|c|c|}
\hline & Weight & 1 & 2 & 3 & 4 & 5 & 6 & 7 & 8 & 9 & 10 \\
\hline Expert 1 & 0,2 & 8,51 & 22,40 & 12,87 & 23,00 & 5,23 & 20,67 & 32,00 & 6,27 & 19,33 & 8,67 \\
\hline Expert 2 & 0,15 & 9,57 & 19,57 & 8,97 & 25,25 & 8,26 & 21,56 & 33,00 & 5,26 & 20,15 & 10,58 \\
\hline Expert 3 & 0,18 & 12,63 & 9,24 & 20,00 & 20,36 & 15,29 & 19,89 & 32,99 & 7,57 & 21,23 & 23,25 \\
\hline Expert 4 & 0,25 & 8,70 & 19,26 & 8,00 & 23,00 & 20,00 & 18,56 & 21,00 & 8,95 & 23,78 & 15,25 \\
\hline Expert 5 & 0,22 & 5,69 & 7,37 & 9,00 & 23,00 & 4,27 & 16,25 & 29,00 & 6,24 & 18,00 & 9,25 \\
\hline & 1 & 8,836 & 15,51 & 10,35 & 22,86 & 10,98 & 19,16 & 28,74 & 7,016 & 20,62 & 13,35 \\
\hline
\end{tabular}

Source: Own results

The most important risk, threatening the development of tourism in the Nizhny Novgorod region, in the opinion of all the experts is the environmental factor, economic factors are in the second place, and marketing factors are on the third place.

The statistical data characterizing the increase in the tourist flow to the Nizhny Novgorod region, as well as the increase in the number of hotels and the number of employees engaged in the tourist industry, make it possible to conclude that at this time it is impossible to diagnose the direct impact of risk factors on the development of tourism on the direct development of this industry. The tourist industry is a growing branch of the Nizhny Novgorod region with broad prospects for development. This is the result of the great tourist potential of the region, rich in not only natural value, but also in cultural and historical values, and attempts to create a tourist cluster, and state support and implementation of many programs that stimulate the development of tourism in the region. However, in the future, if the appropriate measures are not taken, the impact of the identified factors will negatively affect the tourist sphere of the Nizhny Novgorod region and the statistics will not be so optimistic and could jeopardize the sustainable development of tourism in the Nizhny Novgorod region.

In order to reduce the level of risk, we propose the following measures that exert managerial influence on the risk factors identified by experts:

1. Creation of a favorable environmental situation in the region:

- improvement of environmental policy;

- use of alternative fuel sources;

- landscaping of the territory;

- improvement of conditions for dispersion of emissions, removal of fugitive and reduction of vented emissions;

- development and implementation of innovative technologies for cleaning atmospheric air and reducing industrial emissions into the atmosphere. 
2. Improvement of the economic mechanism of development of tourism in the region:

- improvement of the energy infrastructure;

- raising the living standards of the population in the region, increasing the level of assimilation of the population, reducing migration;

- providing state support for the development of tourism in the region (providing tax benefits, subsidies, co-financing of economic projects for the development of the tourism industry).

3. The formation of a favorable image of the region in the domestic and world tourism market:

- information and analytical propaganda;

- advertising of the national tourist product;

- concluding international agreements in the field of tourism development;

- improving the service quality, improvement of the qualification of the personnel of the hotel and restaurant businesses.

\section{Conclusions}

Our results are based on the findings that used specific tools and methods. In the course of our study, we identified the main risk factors for the development of the tourism industry in the Nizhny Novgorod region. Using the Saati's method of hierarchies, the groups of risk factors were ranked according to the degree of influence on the economy of the region and the factors that exerted the strongest influence were determined: ecological, economic and marketing ones.

Our results and findings show that up to date, the identified factors do not have a strong impact on the economy of the region and the development of tourism according to the statistical data showing a positive dynamics of tourism development in the region, but in the future risks can negatively affect the main economic indicators. Proposed measures of the preventive policy to neutralize the identified factors can prevent problems in the tourism industry provided they are applied in a timely manner.

\section{References}

Abrhám J, Wang J (2017) Novel trends on using ICTS in the modern tourism industry. Czech Journal of Social Sciences, Business and Economics 6(1):37-43. doi: 10.24984/cjssbe.2017.6.1.5

Andergassen R, Guido C, Figini P (2017) The management of tourism destinations: A policy game. Tourism Economics 23(1):49-65. doi: 10.5367/te.2015.0496

Bikas E, Saponaite V (2018) Behavior of the Lithuanian investors at the period of economic growth. Entrepreneurship and Sustainability Issues 6(1):44-59. doi: 10.9770/jesi.2018.6.1(4)

Borisov S (2015) Analysis of factors affecting the investment attractiveness of the Nizhny Novgorod region. Innovative Economics: Materials of the $2^{\text {nd }}$ International Scientific Conference, pp. 104-107.

Dengaev A (2014) Analysis of the methodological foundations of regional tourism management in conditions of risk and uncertainty. Scientific and methodical electronic journal "Concept" 20:2561-2565.

Han L, Song H (2017) New Evidence of Dynamic Links between Tourism and Economic Growth Based on Mixed-Frequency Granger Causality Tests. Journal of Travel Research 57(7):899-907. doi: $10.1177 / 0047287517723531$

Hen YJ, Tsai H, Liu YF (2018) Supply chain finance risk management: Payment default in tourism channels. Tourism Economics 24(5):593-614: doi: 10.1177/1354816618762187

Ioannides D, Apostolopoulos Y, Sönmez S (eds.), Mediterranean islands and sustainable tourism development: Practices, management and policies, $1^{\text {st }}$ edn (Continuum, London, 2001), 308 p.

Karl M (2016) Risk and Uncertainty in Travel Decision-Making: Tourist and Destination Perspective. Journal of Travel Research 19:129-146. doi: 10.1177/0047287516678337 
Kirillova SO (2017) Research of the problem of development of tourism as the country's fundamental branch. Economics and management of innovative technologies. http://ekonomika.snauka.ru/2017/04/14585 Accessed 27 Aug 2018

Kochkurova E, Zykova T (2018) Research and assessment of recreational capacity of the Nizhny Novgorod region Journal of Media Critiques 4 (14):99-106. doi: 10.17349/jmc118200

León C, Araña J, González M, León J (2014) Tourists' Evaluation of Climate Change Risks in the Canary Islands: A Heterogeneous Response Modeling Approach. Tourism Economics 20(4):849-868. doi: $10.5367 /$ te. 2013.0310

Nordin S (2003) Tourism clustering and innovation: the path to economic growth and development. European Tourism Research Institute. http://www.etour.se/download Accessed 28 Aug 2018

Oláh J, Bai A, Karmazin Gy, Balogh P, Popp J (2017) The Role Played by Trust and Its Effect on the Competiveness of Logistics Service Providers in Hungary. Sustainability 9(12):2303. doi:10.3390/su9122303

Oppenov (2018) Nizhny Novgorod Open Portal. https://opennov.ru/news/32259-turpotok-v-nizhegorodskuyuoblast-v-2016-godu-vyros-na-34 Accessed 27 Aug 2018

Piekarz M, Jenkins I, Mills P (2015) Risk and safety management in the leisure, events, tourism and sports industries, $1^{\text {st }}$ edn. (CABI, Wallingford, Oxfordshire, 2015), 283 p.

Poudel S, Nyaupane G, Budruk M (2014) Stakeholders' Perspectives of Sustainable Tourism Development A New Approach to Measuring Outcomes. Journal of Travel Research 55(4):465-480. doi:10.1177/0047287514563166

Strielkowski W (2017) Promoting Tourism Destination through Film-Induced Tourism: The Case of Japan. Market-Trziste 29(2):193-203. doi:10.22598/mt/2017.29.2.193

Strielkowski W (2018) Film-induced tourism. Journal of Hospitality and Tourism Management 36:117-118. doi: 10.1016/j.jhtm.2017.10.005

Strielkowski W, Chigisheva O (2018) Social, Economic, and Academic Leadership for Sustainable Development of Business and Education in the Future: An Introduction. In: Strielkowski W., Chigisheva O. (eds.) Leadership for the Future Sustainable Development of Business and Education. Springer Proceedings in Business and Economics. Springer, Cham, pp. 3-8. doi: 10.1007/978-3-319-74216-8_1

Strielkowski W, Riganti P, Jing W (2012) Tourism, cultural heritage and e-services: Using focus groups to assess consumer preferences. Tourismos: an International Multidisciplinary Journal of Tourism 7(1):41 -60.

Subačienė R, Alver L, Brūna I, Hladika M, Mokošová D, Molín J (2018) Evaluation of accounting regulation evolution in selected countries. Entrepreneurship and Sustainability Issues 6(1):139-175. doi: 10.9770/jesi.2018.6.1(11)

Williams A, Baláž V (2014) Tourism Risk and Uncertainty. Theoretical Reflections. Journal of Travel Research 54 (3):271-287. doi: 10.1177/0047287514523334

Yang E (2015) Tourists' risk perception of risky destinations: The case of Sabah's eastern coast. Tourism and Hospitality Research 15(3): 206-221. Doi:10.1177/1467358415576085 